\section{Optimizing the Storage Temperature and Humidity for Fresh Cranberries: A Reassessment of Chilling Sensitivity}

\author{
Charles F. Forney ${ }^{1}$ \\ Agriculture and Agri-Food Canada, Atlantic Food and Horticulture \\ Research Centre, 32 Main Street, Kentville, Nova Scotia B4N 155 Canada
}

Additional index words. Vaccinium macrocarpon, fruit quality, decay, physiological breakdown, firmness, storage, temperature, humidity

\begin{abstract}
Studies were conducted over three seasons to determine the relationship of temperature and humidity on the storage life of fresh cranberry (Vaccinium macrocarpon Aiton) fruit. Each year, cranberries harvested from four commercial bogs were stored at temperatures ranging from 0 to $10{ }^{\circ} \mathrm{C}$ in combination with relative humidities (RH) ranging from $75 \%$ to $98 \%$. Fruit were stored under these conditions for up to 6 months and were evaluated monthly for marketability, decay, physiological breakdown, weight loss, and firmness immediately after removal and after an additional week at $20{ }^{\circ} \mathrm{C}$. The percentage of marketable fruit declined substantially over time in all storage conditions with $41 \%$ to $57 \%$ becoming unmarketable after 2 months as a result of both decay and physiological breakdown. Relative humidity had a greater effect on fruit storage life than temperature and after 5 months, the amount of marketable fruit stored in high $(98 \%)$ and medium $(88 \%)$ RH was $71 \%$ and $31 \%$ less than that stored in low $\mathbf{7 5 \%}$ to $82 \%)$ RH. Rates of fresh weight loss increased as RH in storage decreased and was $0.41 \%, 0.81 \%$, and $0.86 \%$ per month in fruit stored in high, medium, and low RH, respectively. Fruit firmness was not significantly affected by $R H$. The effects of storage temperatures ranging from 0 to $7^{\circ} \mathrm{C}$ on marketable fruit after 2 to 5 months of storage were not significant. Only fruit stored at $10^{\circ} \mathrm{C}$ consistently had fewer marketable fruit when compared with fruit stored at lower temperatures. Storage temperature had no significant effect on decay incidence. However, physiological breakdown was greatest in fruit stored at $10{ }^{\circ} \mathrm{C}$. Rates of fresh weight loss increased with storage temperature, ranging from $0.35 \%$ to $1.17 \%$ per month for fruit stored at 0 to $10{ }^{\circ} \mathrm{C}$, respectively. Contrary to previous reports, no evidence of chilling injury was found in cranberry fruit stored at $0{ }^{\circ} \mathrm{C}$. Results suggest that cranberry fruit should be stored at 0 to $7^{\circ} \mathrm{C}$ and $75 \%$ to $82 \%$ RH to retain marketable fruit.
\end{abstract}

There is an increased interest in extending the market life of fresh cranberries as a result of the growing demand for fresh, healthful fruits. To supply this growing demand, fruit quality must be maintained and postharvest losses reduced during extended storage and marketing periods. However, for a variety of known and unknown reasons, successful storage of fresh cranberries has been variable and fruit loss is often excessive.

\footnotetext{
Received for publication 12 Feb. 2007. Accepted for publication 23 Mar. 2007

Contribution No. 2333 of the Atlantic Food and Horticulture Research Centre.

I thank Carolyn Domytrak, Michele Elliot, Stephanie Bishop, Vivian Agar, and Michael Jordan for technical support; Dr. Kenneth B. McRae and Sherry Fillmore for providing statistical analysis; Bezanson \& Chase Cranberry Co Ltd., Aylesford, NS and Cranberry Acres Farms, Aylesford, NS for providing fruit and financial support; the Nova Scotia Technology Development Program and the Agriculture and Agri-Food Canada Matching Investment Initiative for providing financial support; and D. Mark Hodges and Wendy Schotsmans for their critical reviews of this manuscript. ${ }^{1}$ Postharvest Physiologist. To whom reprints should be addressed; e-mail forneyc@agr.gc.ca
}

Unlike most fruit, the optimum conditions for the storage of fresh cranberry fruit are not clearly defined. In various handbooks published in the past 20 years, recommended storage temperatures range from 2 to $7{ }^{\circ} \mathrm{C}$ (Hardenburg et al., 1986; Kader, 1997; Kasmire and Thompson, 1992; Lidster et al., 1988; Prange, 2004; Spayd et al., 1990). Similarly, the relative humidity $(\mathrm{RH})$ for storage recommended in these handbooks ranges from $80 \%$ to $95 \%$. These recommendations are based on a limited number of studies, most being conducted over 60 years ago (Levine et al., 1941; Wright et al., 1937). These variable recommendations reflect the lack of clear differences reported in these studies, which may reflect inherent fruit properties that are influenced by cultural conditions, cultivars, harvest method, postharvest handling, and storage environment.

Postharvest loss of cranberry fruit is primarily the result of physiological breakdown and decay (Forney, 2003). Physiological breakdown is associated with overmature fruit (Doughty et al., 1968), bruising (Patterson et al., 1967), chilling injury (CI) (Hruschka, 1970), freezing (Bristow and Patten, 1995), extended water immersion (Ceponis and Stretch, 1983), and anoxia (Stark et al.,
1974) and is characterized by a dull appearance, rubbery texture, and diffusion of red pigment throughout the fruit flesh (Bristow and Patten, 1995). Decay is caused by a complex of fungal organisms, including Allantophomopsis lycopodina (Hohn.) Carris (black rot), Allantophomopsis cytisporea (Fr.:Fr.) Petr. (black rot), Strasseria geniculata (Berk.\& Br.) Höhnel (black rot), Coleophoma empetri (Rostr.) Petr. (ripe rot), Fusicoccum putrefaciens Shear. (end rot), Phyllosticta elongata G.J. Weidemann (berry speckle), Physalospora vaccinii (Shear) Arx \& E. Müller (blotch rot), and Botrytis spp. (yellow rot) (Boone, 1995a, 1995b; Carris, 1995; Caruso, 1995; Oudemans et al., 1998; Pepin and Boone, 1995). Infection of the fruit may occur during bloom or wet harvest in the case of fungi causing black rot. Decay is characterized by external lesions and often only part of the internal flesh is red, whereas the unaffected flesh remains white. Unlike most postharvest decays in other crops, there is little spread of disease from infected to healthy fruit in storage (Oudemans et al., 1998).

Contributing to the uncertainty of optimum storage temperature is the fact that cranberries are reported to be chilling-sensitive and may develop physiological breakdown (CI) when stored at temperatures less than $2.2^{\circ} \mathrm{C}$ (Levine et al., 1941; Wright et al., 1937). Chilling sensitivity of fruit may be affected by environmental, cultural, or genetic factors, which can alter their response to storage temperature (Patterson and Reid, 1990). In addition, fungal species and races causing fruit decay may vary depending on growing location (Caruso and Ramsdell, 1995). Therefore, decay development may be different in similar storage environments depending on the pathogens present (Bristow and Patten, 1995).

Most berry crops benefit from $\mathrm{RH}$ in storage of $95 \%$ or greater, which is effective in reducing water loss that would result in shriveling and physiological stress. However, reports indicate that cranberries store better in lower RH with suggested optimum storage RH being $65 \%$ to $70 \%$ (Stark et al., 1974) or $70 \%$ to $75 \%$ (Wright et al., 1937). However, in storage handbooks, recommendations are $80 \%$ to $90 \%$ (Lidster et al., 1988 ) and $90 \%$ to 95\% RH (Hardenburg et al., 1986; Kader, 1997; Spayd et al., 1990). These higher recommended RHs are most likely influenced by the positive response of other fruit to high $\mathrm{RH}$.

To clarify storage recommendations, a study was conducted to reassess the effects of temperature and $\mathrm{RH}$ on cranberry storage life. The objectives of this study were to determine the relationship among storage temperature, $\mathrm{RH}$, and cranberry fruit storage life and assess the chilling sensitivity of cranberry fruit.

\section{Materials and Methods}

Fruit. Storage experiments were conducted over three harvest seasons from 2001 to 2003 
to evaluate the effects of temperature and $\mathrm{RH}$ on the quality and storage life of fresh cranberries. Each year, mechanically harvested fruit from four commercial bogs were stored for up to 6 months. In 2001, 'Stevens' cranberry fruit were harvested from two bogs in Aylesford, Nova Scotia, using a wet-rake harvester and one bog in Aylesford, Nova Scotia, and one bog in Wisconsin using wetbeater harvesters. In 2002, 'Stevens' cranberry fruit were harvested from four bogs in Alyesford, Nova Scotia; two bogs were harvested using a wet-rake harvester and two were harvested using a wet-beater harvester from a second grower. In 2003, cranberry fruit were harvested from four bogs in Nova Scotia, representing four commercial growers and three cultivars. Two bogs of 'Stevens' were harvested using dry-rake harvesters from commercial bogs in Amherst and Lawrencetown, Nova Scotia, 'Pilgrim' fruit were harvested from a commercial bog in Centrelea, Nova Scotia, using a wet-rake harvester, and 'Bergman' fruit were harvested from a commercial bog in Aylesford, Nova Scotia, using a wet-rake harvester. All fruit were harvested between mid-October and early November. Fruit were transported to the Atlantic Food and Horticulture Research Center in commercial lugs and held at $5{ }^{\circ} \mathrm{C}$ and $80 \% \mathrm{RH}$ for no more than 14 $\mathrm{d}$ before being used in storage experiments. Fruit from each bog was randomized and placed into Olympian SP\#5 5.25-inch square nursery pots (Nursery Supplies, Chambersburg, PA) with a volume of $1.95 \mathrm{~L}$ and a depth of $15.3 \mathrm{~cm}$, which is similar to the depth of commercial storage containers. Individual containers held $\approx 900 \mathrm{~g}$ of fruit. Containers were used to hold fruit for storage experiments and served as units for sampling and evaluating fruit.

Storage conditions. For storage experiments, containers of cranberries were held in $60-\mathrm{L}$ plastic tubs. Each tub contained 12 containers of cranberries, six from each of two bogs. Containers of cranberries were randomized and stacked in a four-container $\times$ three-level arrangement inside each tub. Containers of cranberries were maintained in the same position throughout the storage experiment. Tubs were sealed with a lid that had a 4-mm diameter hole in the center to provide aeration.

Temperature and humidity. Tubs containing fruit were stored in walk-in controlled- temperature chambers maintained at $0,3,5$, 7 , or $10^{\circ} \mathrm{C}$ to study the effects of temperature on fruit storage life. Two chambers for each temperature were used each year with bogs being nested in chambers. Tubs containing fruit from two of the four bogs were stored in one series of chambers at each temperature, whereas tubs containing the fruit from the other two bogs were stored in the second series of chambers.

In the 2001 season, no attempt was made to control RH in the tubs. However, chamber temperatures were monitored hourly and the temperature and $\mathrm{RH}$ within tubs was measured after 2, 4, and 6 months. From these observations, it appeared that temperature was maintained within $0.5^{\circ} \mathrm{C}$ of the target temperature and $\mathrm{RH}$ averaged $\approx 82 \%$.

In 2002, "low" or "medium" RH was obtained by placing low RH tubs in the temperature-controlled chambers uncovered as done in 2001, whereas medium RH tubs were sealed in a ventilated plastic garbage bag containing one 4-mm hole near the bottom of the tub. Relative humidity and temperature of the room and each tub were measured immediately before fruit removal using a RH5100 humidity dew point temperature meter (Omega, Stamford, CT) or a 21X Micrologger with a temperature and relative humidity probe (Campbell Scientific, Edmonton, Alberta, Canada). Measurements were obtained by placing the probe $\approx 30 \mathrm{~cm}$ into the tub through a resealable hole in the top of the lid. The temperature in the low RH tubs averaged 0.2 to $0.9{ }^{\circ} \mathrm{C}$ higher than target storage temperature over the 6 months of storage (Table 1). The RH in the low RH tubs ranged from $77 \%$ to $86 \%$ and averaged $82 \%$. The temperature in the medium RH tubs averaged $\approx 0.2{ }^{\circ} \mathrm{C}$ higher than temperatures in the low RH tubs. The RH in the medium $\mathrm{RH}$ tubs ranged from $81 \%$ to $88 \%$ and averaged $86 \%$.

In $2003,1.5 \mathrm{~kg}$ of salts was placed in the bottom of each tub to maintain three different $\mathrm{RH}$ levels. A $3.5 \times 18 \times 27-\mathrm{cm}$ plastic tray was used to elevate the containers of berries above the salt. The salts used to obtain a "low," "medium," and "high" RH were calcium nitrate $\left(\mathrm{CaNO}_{3}\right)$, sodium chloride $(\mathrm{NaCl})$, and potassium nitrate $\left(\mathrm{KNO}_{3}\right)$, which have equilibrium RHs of $66 \%, 76 \%$, and $96 \%$, respectively, across the 0 to $10{ }^{\circ} \mathrm{C}$ temperature range (O'Brien, 1948). Tubs were placed in the temperature-controlled chambers and sealed in ventilated plastic garbage bags. Temperature and RH of each tub in one of the two chambers at each temperature was monitored using HOBO data loggers (Onset Computer Corp., Bourne, MA) suspended in the center of the tub. Over the 6 months of storage, the temperature in the tubs averaged within 0.2 to $0.8^{\circ} \mathrm{C}$ of the target storage temperatures (Table 1). The $\mathrm{RH}$ in tubs containing the $\mathrm{CaNO}_{3}, \mathrm{NaCl}$, and $\mathrm{KNO}_{3}$ averaged $75 \%, 88 \%$, and $98 \%$, respectively, during the storage period.

Fruit quality analysis. At harvest, three containers of fruit from each cranberry bog were evaluated for initial quality. In addition, fruit quality was assessed at monthly intervals for 6 months, at which time one container of cranberries representing each bog and storage treatment was removed from storage. Fruit were evaluated for color, fresh weight loss, firmness, decay, physiological breakdown, and marketable fruit. After fruit showing signs of decay or physiological breakdown were removed from each sample, $340 \mathrm{~g}$ of marketable fruit were bagged in perforated polyethylene cranberry bags and held for 1 additional week in air at $20{ }^{\circ} \mathrm{C}$. After the week holding period, fruit quality was evaluated as previously described.

Color was assessed as white (less than $50 \%$ red) or red (greater than $50 \%$ red). Decayed fruit were identified by discoloration and softening. Fruit with physiological breakdown were identified by a dull appearance, rubbery texture, and diffusion of red pigment throughout the flesh. Marketable fruit was calculated as the fruit remaining after all fruit with decay or physiological breakdown were removed from the sample. Fruit identified as white, decay, physiological breakdown, and those considered marketable were all weighed and expressed as a percentage of the total fruit weight.

Firmness was measured using a FirmTech1 firmness testing instrument (BioWorks, Stillwater, OK). A subsample of 25 marketable cranberries from each container was placed on its side in the index holes of the FirmTech1 turntable. A 15-mm diameter load plate compressed each fruit at a rate of $10 \mathrm{~mm} \cdot \mathrm{s}^{-1}$ to a maximum threshold force of $1.96 \mathrm{~N}$. The average firmness of each 25 cranberry subsample was recorded in $\mathrm{N} \cdot \mathrm{mm}^{-1}$ of deformation. In the event that a 25 cranberry subsample was not available for analysis, as a result of low percentages of

Table 1. Recorded temperature (T) and relative humidity (RH) in plastic tubs during storage of cranberry fruit during the 2002 and 2003 storage seasons. ${ }^{2}$

\begin{tabular}{|c|c|c|c|c|c|c|c|c|c|c|}
\hline \multirow{3}{*}{$\begin{array}{l}\text { Season } \\
\text { Humidity } \\
\text { Target temperature }\end{array}$} & \multicolumn{4}{|c|}{2002} & \multicolumn{6}{|c|}{2003} \\
\hline & \multicolumn{2}{|c|}{ Low } & \multicolumn{2}{|c|}{ Medium } & \multicolumn{2}{|c|}{ Low } & \multicolumn{2}{|c|}{ Medium } & \multicolumn{2}{|c|}{ High } \\
\hline & $\mathrm{T}\left({ }^{\circ} \mathrm{C}\right)$ & RH (\%) & $\mathrm{T}\left({ }^{\circ} \mathrm{C}\right)$ & $\mathrm{RH}(\%)$ & $\mathrm{T}\left({ }^{\circ} \mathrm{C}\right)$ & $\mathrm{RH}(\%)$ & $\mathrm{T}\left({ }^{\circ} \mathrm{C}\right)$ & $\mathrm{RH}(\%)$ & $\mathrm{T}\left({ }^{\circ} \mathrm{C}\right)$ & RH (\%) \\
\hline $0^{\circ} \mathrm{C}$ & $0.5 \pm 0.5^{y}$ & $86 \pm 2$ & $0.7 \pm 0.5$ & $88 \pm 1$ & $0.0 \pm 0.3$ & $72 \pm 2$ & $-0.1 \pm 0.2$ & $91 \pm 1$ & $-0.4 \pm 0.3$ & $93 \pm 1$ \\
\hline $3{ }^{\circ} \mathrm{C}$ & $3.2 \pm 0.3$ & $85 \pm 3$ & $3.5 \pm 0.3$ & $88 \pm 1$ & $2.5 \pm 0.2$ & $81 \pm 9$ & $2.6 \pm 0.2$ & $85 \pm 4$ & $2.9 \pm 0.0$ & $97 \pm 2$ \\
\hline $5^{\circ} \mathrm{C}$ & $5.9 \pm 0.6$ & $84 \pm 4$ & $5.9 \pm 0.7$ & $88 \pm 1$ & $6.2 \pm 0.5$ & $71 \pm 3$ & $5.5 \pm 0.2$ & $90 \pm 2$ & $5.7 \pm 0.4$ & $99 \pm 2$ \\
\hline $7{ }^{\circ} \mathrm{C}$ & $7.5 \pm 0.4$ & $80 \pm 3$ & $7.8 \pm 0.5$ & $86 \pm 2$ & $6.8 \pm 0.1$ & $76 \pm 5$ & $6.5 \pm 0.1$ & $84 \pm 6$ & $6.7 \pm 0.1$ & $91 \pm 6$ \\
\hline $10{ }^{\circ} \mathrm{C}$ & $10.8 \pm 0.3$ & $77 \pm 3$ & $11.1 \pm 0.5$ & $81 \pm 4$ & $9.9 \pm 0.3$ & $73 \pm 10$ & $10.0 \pm 0.2$ & $88 \pm 4$ & $9.7 \pm 0.3$ & $98 \pm 2$ \\
\hline
\end{tabular}

"In the 2002 season, the "low" and "medium" RH were maintained by sealing the "medium" RH tubs in a ventilated plastic bag. In the 2003 season, the "low," "medium," and "high" RHs were maintained by placing $\mathrm{CaNO}_{3}, \mathrm{NaCl}$, and $\mathrm{KNO}_{3}$ salts, respectively, in the bottom of tubs and sealing the tubs in ventilated plastic bags.

${ }^{\mathrm{y}}$ Mean $\pm \mathrm{SD} ; \mathrm{n}=20$ for $2002, \mathrm{n}=138$ for 2003 . 
marketable fruit, an average was obtained from the available fruit.

Statistical analysis. Data from all 3 years were combined for analysis. The RH treatments were grouped as low, medium, and high. The low RH group was comprised of all 2001 data, the 2002 low RH treatment, and the $2003 \mathrm{CaNO}_{3}$ treatment; the medium $\mathrm{RH}$ group was comprised of the 2002 medium RH treatment and the $2003 \mathrm{NaCl}$ treatment; and the high RH group was comprised of the $2003 \mathrm{KNO}_{3}$ treatment. To account for the unbalanced design, data were analyzed using the Restricted Maximum Likelihood (REML) procedure of GenStat (Payne, 2003) to determine fixed effects among temperature $(0,3$, $5,7,10^{\circ} \mathrm{C}$ ), $\mathrm{RH}$ (low, medium, high), storage time $(1,2,3,4,5,6$ months), and their interactions. The REML procedure tested variation in the effects of temperature and $\mathrm{RH}$ among years and cultivars and within years to account for unbalanced treatments and treatment combinations. Year was assigned as a random factor in the model, which removed variation differences resulting from year. The model used the common cultivar ('Stevens') among years to adjust year-toyear variation and variation resulting from the additional cultivars in year 3 . For each temperature, berries from four cranberry bogs were randomly assigned to two chambers. Within a chamber, the humidity treatments were randomized to tubs and removals were randomized across levels within a tub. Data expressed as a percentage were transformed using an angular transformation to normalize the distribution. Pairwise t-probabilities among the levels of the main effect and among treatments within the table of interactions were calculated to determine mean separation. Evaluations made immediately after storage and after the 7-d period at 20 ${ }^{\circ} \mathrm{C}$ were analyzed separately.

\section{Results}

Initial quality. Initial fruit quality is described in Table 2. On average over the three seasons, $92 \%$ of the fruit was judged to be marketable before being placed into storage. Of the unmarketable fruit, $\approx 2.7 \%$ showed signs of decay and $4 \%$ had physiological breakdown. The amount of decay and physiological breakdown varied by bog, which is reflected in the large SDs associated with these values. After $7 \mathrm{~d}$ at $20{ }^{\circ} \mathrm{C}, 79 \%$ of the fruit remained marketable. During these 7 $\mathrm{d}, \approx 7 \%$ of the fruit decayed and $14 \%$ developed physiological breakdown. In addition, most of the white fruit turned red. Fruit firmness declined by $4 \%$ and fresh weight by $1.4 \%$.

Storage humidity. Relative humidity in storage affected the quantity of marketable cranberry fruit to a greater extent than temperature did with the greatest losses of marketable fruit occurring in the high $\mathrm{RH}$ (Table 3; Fig. 1A). This effect of RH on marketable fruit increased during storage. After 1 month in storage, marketable fruit stored in the three levels of RH were not sig-

Table 2. Average quality of cranberry fruit immediately after harvest (initial) and after $7 \mathrm{~d}$ at $20{ }^{\circ} \mathrm{C} .{ }^{\mathrm{z}}$

\begin{tabular}{|c|c|c|c|c|}
\hline & \multicolumn{4}{|c|}{ Fruit quality } \\
\hline & \multicolumn{2}{|c|}{ Initial } & \multicolumn{2}{|c|}{ Plus $7 \mathrm{~d}$ at $20^{\circ} \mathrm{C}$} \\
\hline & Mean & SD & Mean & SD \\
\hline Marketable fruit (\%) & 92.1 & 3.9 & 79.0 & 10.1 \\
\hline Decay $(\%)$ & 2.7 & 4.0 & 7.4 & 7.9 \\
\hline Physiological breakdown (\%) & 4.4 & 3.9 & 13.7 & 6.5 \\
\hline Fruit less than $50 \%$ white $(\%)$ & 1.6 & 1.8 & 0.1 & 0.4 \\
\hline Firmness $\left(\mathrm{N} \cdot \mathrm{mm}^{-1}\right)$ & 6.6 & 0.7 & 6.3 & 0.7 \\
\hline Weight loss (\%) & - & - & 1.4 & 0.5 \\
\hline
\end{tabular}

${ }^{2}$ Values are the average of fruit from 12 commercial bogs (four bogs in each of three seasons).

Table 3. Significance of storage temperature $(\mathrm{T})$, relative humidity $(\mathrm{RH})$, storage duration $(\mathrm{S})$, and their interactions on fruit marketability, decay, physiological breakdown (PB), fresh weight (FW) loss, and firmness of cranberry fruit stored at $0,3,5,7$, or $10^{\circ} \mathrm{C}$ in low, medium, or high $\mathrm{RH}$ for up to 6 months. ${ }^{\mathrm{z}}$

\begin{tabular}{|c|c|c|c|c|c|c|}
\hline \multicolumn{7}{|c|}{ A. After storage } \\
\hline \multirow[b]{2}{*}{ Source } & \multirow[b]{2}{*}{$\mathrm{df}$} & \multicolumn{5}{|c|}{ F Probability } \\
\hline & & Marketable & Decay & $\mathrm{PB}$ & FW loss & Firmness \\
\hline Temperature $(\mathrm{T})$ & 4 & $* * *$ & NS & $* * *$ & $* * *$ & $* * *$ \\
\hline Humidity (RH) & 2 & $* * *$ & $* * *$ & $* * *$ & $* * *$ & + \\
\hline Storage Time (S) & 5 & $* * *$ & $* * *$ & $* * *$ & $* * *$ & $* * *$ \\
\hline $\mathrm{T} \times \mathrm{RH}$ & 8 & NS & NS & + & $* * *$ & $* * *$ \\
\hline $\mathrm{T} \times \mathrm{S}$ & 20 & NS & $* *$ & NS & $* * *$ & + \\
\hline $\mathrm{RH} \times \mathrm{S}$ & 10 & $*$ & $* * *$ & $* * *$ & NS & $* * *$ \\
\hline $\mathrm{T} \times \mathrm{RH} \times \mathrm{S}$ & 40 & NS & NS & NS & NS & $* *$ \\
\hline \multicolumn{7}{|c|}{ B. After an additional $7 \mathrm{~d}$ at $20^{\circ} \mathrm{C}$} \\
\hline & & \multicolumn{5}{|c|}{ F Probability } \\
\hline Source & df & Marketable & Decay & $\mathrm{PB}$ & FW loss & Firmness \\
\hline Temperature $(\mathrm{T})$ & 4 & $* * *$ & $* * *$ & $* * *$ & $* *$ & $* * *$ \\
\hline Humidity $(\mathrm{H})$ & 2 & $* * *$ & $* * *$ & $* * *$ & $* * *$ & NS \\
\hline Storage Time $(\mathrm{S})$ & 8 & $* * *$ & $* * *$ & NS & $* * *$ & $* * *$ \\
\hline $\mathrm{T} \times \mathrm{H}$ & 5 & $* * *$ & NS & $*$ & $* * *$ & $* * *$ \\
\hline $\mathrm{T} \times \mathrm{S}$ & 20 & NS & NS & NS & NS & NS \\
\hline $\mathrm{H} \times \mathrm{S}$ & 10 & $*$ & $* * *$ & $* * *$ & $*$ & $* * *$ \\
\hline $\mathrm{T} \times \mathrm{H} \times \mathrm{S}$ & 40 & NS & NS & NS & $* *$ & $*$ \\
\hline
\end{tabular}

${ }^{2}$ Fruit were evaluated immediately after storage (A) or marketable fruit were placed in polyethylene bags and held an additional $7 \mathrm{~d}$ at $20{ }^{\circ} \mathrm{C}$ before evaluation (B). Significance was determined using Restricted Maximum Likelihood.

${ }^{* * *} P<0.001,{ }^{* *} P<0.01,{ }^{*} P<0.05,+P<0.1, \mathrm{Ns}=$ nonsignificant.

nificantly different. However, after 2 months, the high RH stored fruit had $37 \%$ fewer marketable fruit than the low RH stored fruit. This difference increased further during storage and after 5 months, the medium and high RH storages produced $31 \%$ and $71 \%$ fewer marketable fruit than the low RH storage, respectively.

The loss of marketable fruit continued at a higher rate in the high $\mathrm{RH}$ stored fruit after fruit were removed from storage and marketable fruit held an additional $7 \mathrm{~d}$ at $20^{\circ} \mathrm{C}$ (Table 3; Fig. 1B). After 1 month plus $7 \mathrm{~d}$, high RH stored fruit had $13 \%$ less marketable fruit than those stored in low RH, whereas after 3 months plus $7 \mathrm{~d}$, the medium and high $\mathrm{RH}$ stored fruit had $10 \%$ and $41 \%$ fewer marketable fruit, respectively, than the low $\mathrm{RH}$ stored fruit.

The different levels of RH affected both decay and physiological breakdown (Table 3; Fig. 1C, E). After 1 month of storage, decay was greatest in fruit stored in high $\mathrm{RH}$ at $14 \%$ compared with 5\% and $9 \%$ decay in fruit from the medium and low RH storage, respectively. However, as the percentage of decayed fruit increased during the first 4 months of storage, these differences were no longer significant. Physiological break- down was not significantly different after 1 month of storage among fruit from the three storage RHs. However, after 2 months, differences between high and low or medium RH stored fruit were observed, which increased through 5 months of storage. After 5 months, physiological breakdown comprised $52 \%$ of the fruit stored in high RH compared with $36 \%$ and $31 \%$ for the medium and low $\mathrm{RH}$ stored fruit, respectively.

Decay and physiological breakdown of marketable fruit held $7 \mathrm{~d}$ at $20{ }^{\circ} \mathrm{C}$ after storage was also affected by the storage $\mathrm{RH}$ (Table 3; Fig. 1D, F). Decay was greatest in fruit previously stored in the high RH for the first 4 months, reaching $34 \%$ after 3 months plus $7 \mathrm{~d}$. At this time, decay of fruit from the medium RH reached $16 \%$, whereas that from the low RH was $9 \%$. Rates of physiological breakdown in fruit that had been stored in the low $\mathrm{RH}$ remained fairly constant ranging from $10 \%$ to $13 \%$. However, physiological breakdown of fruit stored in high RH was elevated and ranged from $16 \%$ to $22 \%$ after 2 to 6 months.

Fresh weight loss was reduced by elevated RH (Table 3; Fig. 1G). Rates of weight loss, determined by linear regression, for fruit stored in the low, medium, and high RH were 


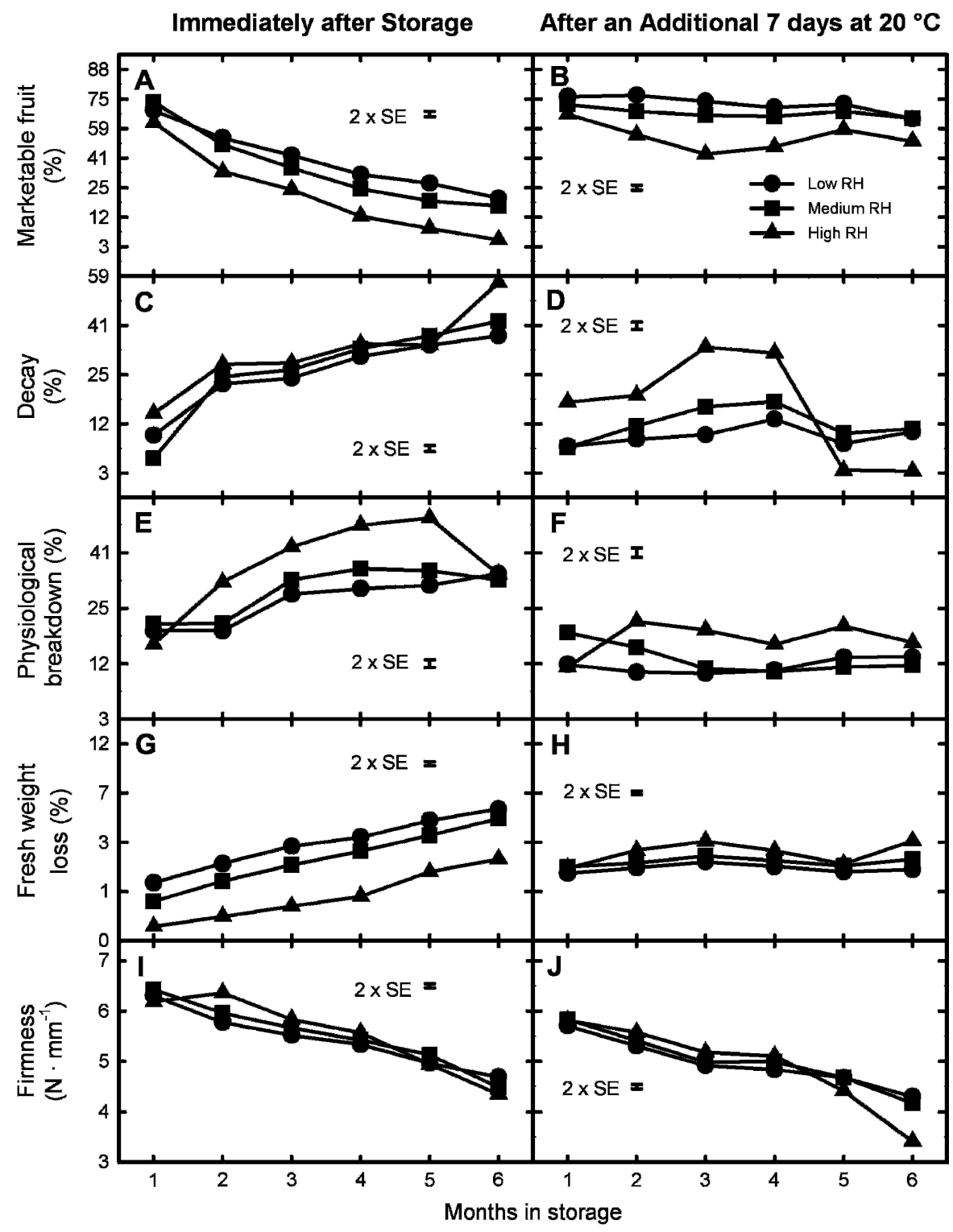

Fig. 1. The effects of storage relative humidity (RH) on the marketability (A-B), decay (C-D), physiological breakdown $(\mathbf{E}-\mathbf{F})$, fresh weight loss $(\mathbf{G}-\mathbf{H})$, and firmness $(\mathbf{I}-\mathbf{J})$ of cranberry fruit evaluated immediately after storage of up to 6 months or after marketable fruit were held an additional $7 \mathrm{~d}$ at $20{ }^{\circ} \mathrm{C}$. Low, medium, and high $\mathrm{RH}$ averaged $75 \%$ to $82 \%, 86 \%$ to $88 \%$, and $98 \%$, respectively. Points are means of fruit from 12 bogs harvested over three seasons and stored at five temperatures. Note the y axis scale represents the angular transformation.

$0.86 \%, 0.81 \%$, and $0.41 \%$ per month, respectively. However, these different rates of weight loss were not reflected in differences in fruit firmness (Table 3; Fig. 1I).

When marketable fruit were held an additional $7 \mathrm{~d}$, fruit stored in the high $\mathrm{RH}$ lost more fresh weight than those stored in the medium or low RH (Fig. 1H). After 3 months of storage, weight loss during the $7 \mathrm{~d}$ at $20{ }^{\circ} \mathrm{C}$ was $3.1 \%, 2.3 \%$, and $1.9 \%$ for fruit stored in the high, medium, and low RH, respectively. Fruit firmness was not significantly affected after the additional $7 \mathrm{~d}$ holding period by the storage RH (Table 3; Fig. 1J).

Storage temperature. Temperature also affected the percentage of marketable fruit after storage (Table 3). After 1 month of storage, the percentage of marketable fruit ranged from $75 \%$ to $62 \%$ for fruit stored at
0 and $10{ }^{\circ} \mathrm{C}$, respectively (Fig. 2A). However, there was no significant difference in marketable fruit stored at 0,3 , or $5{ }^{\circ} \mathrm{C}$. This lack of difference was maintained through 5 months of storage. In addition, after 2 months of storage, the marketability of the fruit stored at $7^{\circ} \mathrm{C}$ was not significantly different from that stored at 0,3 , or $5{ }^{\circ} \mathrm{C}$.

The percentage of marketable fruit declined substantially over time regardless of storage temperature. After the first month of storage, $17 \%$ to $30 \%$ of the marketable fruit were lost when compared with initial values, and after 2 months, $41 \%$ to $57 \%$ were lost. During the remaining 4 months of storage, the percentage of marketable fruit continued to decline but at a slower rate, and after 6 months, $82 \%$ to $92 \%$ of fruit were unmarketable.
When marketable fruit were bagged and held an additional $7 \mathrm{~d}$ at $20{ }^{\circ} \mathrm{C}$, fruit previously stored at higher temperatures maintained more marketable fruit than those previously stored at 0 or $3{ }^{\circ} \mathrm{C}$ (Table 3; Fig. 2B). The bagged fruit previously stored at 7 or $10{ }^{\circ} \mathrm{C}$ for 1 month had $75 \%$ marketable fruit compared with $66 \%$ from the $0{ }^{\circ} \mathrm{C}$ storage. This difference was accentuated after 6 months of storage, where marketable fruit was maintained at greater than $70 \%$ in fruit previously stored at 7 or $10^{\circ} \mathrm{C}$ compared with only $47 \%$ when stored at $0{ }^{\circ} \mathrm{C}$. Maintenance of fruit quality after storage at 7 or $10^{\circ} \mathrm{C}$, and to a lesser extent $5^{\circ} \mathrm{C}$, was maintained during the additional 7-d holding period throughout the 6-month experiment at levels similar to those measured for the initial levels. However, marketability of fruit that had been stored at either 0 or $3{ }^{\circ} \mathrm{C}$ declined with increasing storage duration.

Loss of marketable fruit was caused by increases in decay and physiological breakdown (Fig. 2C, E). When fruit were evaluated immediately after storage, storage temperature did not significantly affect decay (Table 3 ). Decay increased from $9 \%$ after 1 month to $46 \%$ after 6 months of storage. Physiological breakdown was affected by storage temperature and was least at 0 or $3{ }^{\circ} \mathrm{C}$ and greatest at $10{ }^{\circ} \mathrm{C}$. After 1 month of storage, $14 \%$ and $25 \%$ of fruit developed physiological breakdown when stored at 0 and $10{ }^{\circ} \mathrm{C}$, respectively. These differences were maintained through 5 months of storage at which time $33 \%$ and $49 \%$ developed physiological breakdown. However, after 6 months, these differences were lost as a result of increases in decay.

Both decay and physiological breakdown were affected by prior storage temperature when marketable fruit were bagged after storage (Table 3). Decay was greater in fruit previously stored at the low temperatures of 0 and $3{ }^{\circ} \mathrm{C}$ and increased during the first 4 months of storage (Fig. 2D). Similarly, physiological breakdown was also greater in 0 and $3{ }^{\circ} \mathrm{C}$ stored fruit (Fig. 2F). However, quantities of fruit developing physiological breakdown remained fairly constant during the first 4 months of storage, ranging from $8 \%$ to $18 \%$, which were similar to the physiological breakdown observed with the initial levels. After 5 months of storage, physiological breakdown of fruit stored at $0{ }^{\circ} \mathrm{C}$ increased to $\approx 28 \%$. This increase coincided with a decrease in decay resulting in a similar drop in marketable fruit.

Fresh weight loss increased as storage duration and temperature increased (Table 3; Fig. 2G). Rates of fresh weight loss, determined by linear regression, were $0.35 \%$, $0.40 \%, 0.59 \%, 1.13 \%$, and $1.17 \%$ per month for fruit stored at $0,3,5,7$, and $10{ }^{\circ} \mathrm{C}$, respectively. After storage, marketable fruit lost $1.5 \%$ to $2.5 \%$ fresh weight during the additional week at $20{ }^{\circ} \mathrm{C}$ and this rate of loss remained constant regardless of the prior storage temperature or duration (Fig. $2 \mathrm{H}$ ).

Fruit firmness followed a similar trend decreasing with storage duration; however, 


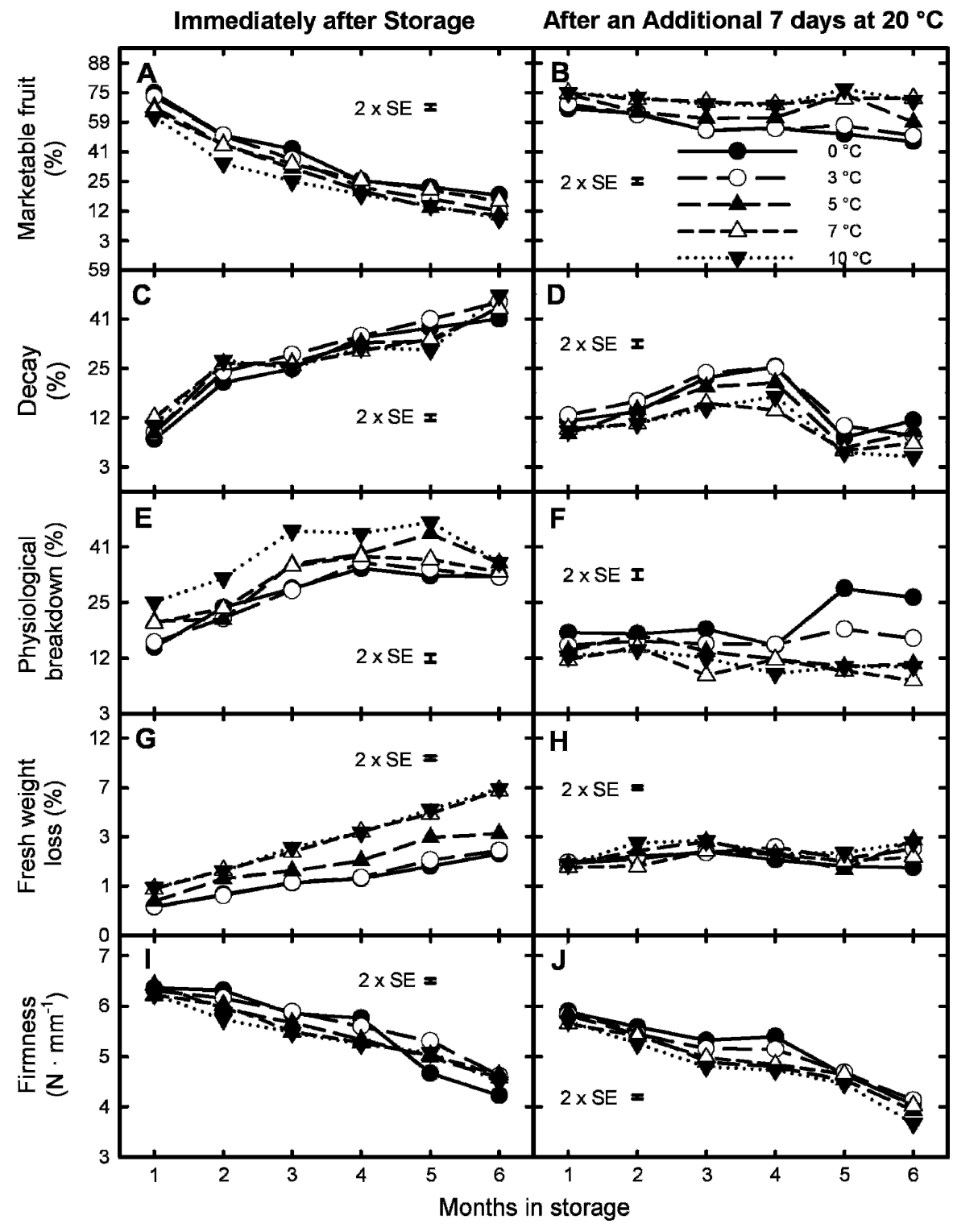

Fig. 2. The effects of storage temperature on the marketability (A-B), decay (C-D), physiological breakdown $(\mathbf{E}-\mathbf{F})$, fresh weight loss $(\mathbf{G}-\mathbf{H})$, and firmness $(\mathbf{I}-\mathbf{J})$ of cranberry fruit evaluated immediately after storage of up to 6 months or after marketable fruit were held an additional $7 \mathrm{~d}$ at $20^{\circ} \mathrm{C}$. Points are the means of fruit from 12 bogs harvested over three seasons and stored in three levels of humidity. Note the y axis scale represents the angular transformation.

the effect of temperature, although significant, was more variable (Table 3; Fig. 2I). Fruit stored at temperatures from 3 to $10^{\circ} \mathrm{C}$ lost firmness at rates averaging 0.31 to $0.35 \mathrm{~N} \cdot \mathrm{mm}^{-1}$ per month. Fruit stored at $0{ }^{\circ} \mathrm{C}$ lost firmness at a similar rate for the first 4 months, but then softened at a higher rate for the remaining 2 months. Fruit firmness continued to decrease during the $7 \mathrm{~d}$ at $20^{\circ} \mathrm{C}$ and averaged 0.39 to $0.78 \mathrm{~N} \cdot \mathrm{mm}^{-1}$ less than fruit measured immediately after storage (Fig. 2J). Fruit previously stored at higher temperatures tended to lose more firmness.

\section{Discussion}

The storage life of cranberry fruit, as assessed by marketability, was affected more by storage $\mathrm{RH}$ than by temperature. The greater loss of cranberry fruit stored at high
RH was also reported in other studies. Wright et al. (1937) found that cranberries better maintained quality when stored in $70 \%$ to $75 \% \mathrm{RH}$ compared with $90 \%$ to $95 \% \mathrm{RH}$. In extended storage of cranberries under a nitrogen atmosphere, Stark et al. (1974) found that fruit stored in $65 \%$ to $70 \% \mathrm{RH}$ had less decay than fruit stored in $90 \%$ to 95\% RH. Likewise, decay and physiological breakdown were higher in fruit stored in polyethylene bags or liners that maintained high RH than in fruit stored in boxes, wellventilated bags, or unlined cartons (Anderson et al., 1963; Hruschka, 1970). In a series of experiments that looked at the storage of fresh cranberries in bulk storage containers, Norton (1982) concluded that storage rot was minimized when adequate ventilation was maintained through the containers and $\mathrm{RH}$ was held $\approx 70 \%$. He further suggested that storage rot was minimized when fruit weight loss was maintained at $1 \%$ every $12 \mathrm{~d}$.

Reducing $\mathrm{RH}$ in the storage tubs increased fresh weight loss of the fruit reflecting the differences in RH. Weight loss provides a better integrated measure of $\mathrm{RH}$ and vapor pressure deficit (VPD) than direct measure of these parameters as a result of variation of $\mathrm{RH}$ and temperature and error associated with their measurement (van den Berg and Lentz, 1978). However, the rate of weight loss in the low RH treatment was approximately three times less $(0.86 \%$ versus $2.5 \%$ every month) than the optimum rate suggested by Norton (1982). Although the $\mathrm{RH}$ in the low RH treatments was similar to that reported by Norton, the difference in air movement around the fruit may account for the large difference in weight loss. Interestingly, the higher rates of weight loss seen at low $\mathrm{RH}$ did not result in softer fruit. This contrasts with other fruit such as bell peppers that have a higher incidence of soft fruit when stored in low RH (Polderdijk et al., 1993). Cranberry fruit softened more rapidly as storage temperature increased suggesting that firmness loss may be the result of metabolically controlled changes in cell wall structure or other processes rather than turgor pressure loss. Turgor pressure loss, which is associated with dehydration and texture loss, may have been minimized by osmotic adjustment within the cells (Pomper and Breen, 1997) or by modification of cellular structure (Levitt, 1986).

The driving force of water loss in stored fruit is the VPD between the storage atmosphere and the fruit. The VPD is a function of both the temperature and the $\mathrm{RH}$ of the storage environment. Assuming the $\mathrm{RH}$ of the interior of the fruit is near saturation, the VPD can be calculated based on the temperature and $\mathrm{RH}$ of the storage environment and the fruit temperature. When the VPD, calculated from the average temperature and $\mathrm{RH}$ in each of the storage treatments, was plotted against the average marketable fruit, a positive correlation was found with VPD accounting for approximately half of the variation in marketable fruit (Fig. 3). Both fruit decay and physiological breakdown were greater at low VPD, but this relationship was strongest for decay.

These effects of humidity on cranberry storage life are contrary to the response of most fresh fruits and vegetables. Generally, high RH minimizes weight loss and water stress on fresh produce, which often delays senescence and decay (Hardenburg et al., 1986; Paull, 1999; van den Berg and Lentz, 1978). However, in cranberries, high RH resulted in increased rates of both decay and physiological breakdown. Water stress induced by low RH may impart resistance to other stresses by affecting growth regulator levels (Grierson and Wardowski, 1978). Low RH may also alter gas diffusion into and out of the fruit, which may affect storage life (Lidster, 1990). The optimum RH favoring pathogen development may vary among pathogens (Grierson and Wardowski, 1978), 


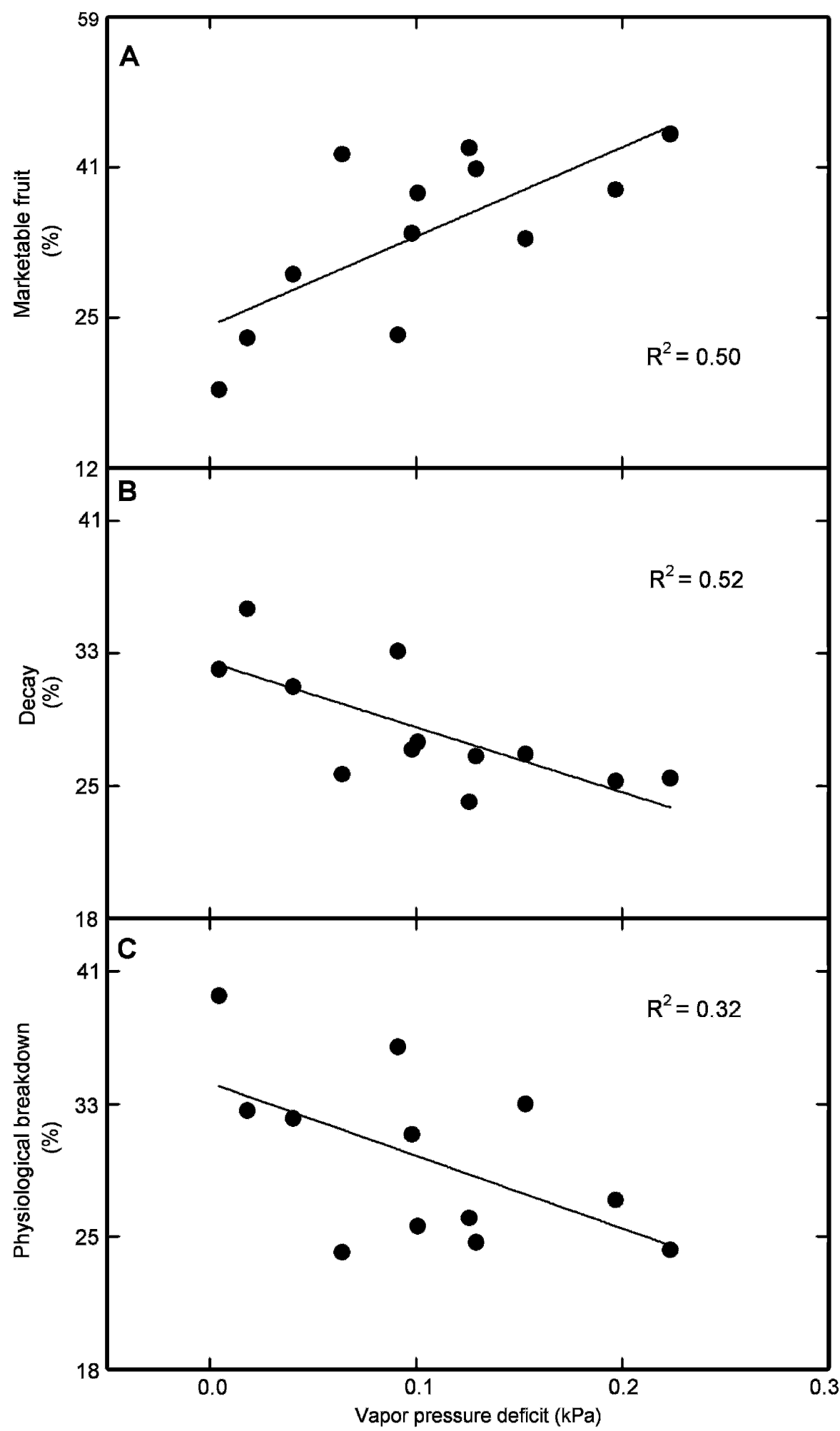

Fig. 3. The relationship of vapor pressure deficit (VPD) with the marketability (A), decay (B), and physiological breakdown $(\mathbf{C})$ of cranberry fruit evaluated immediately after storage. Points are the means of fruit stored for 1, 2, 3, 4, 5, or 6 months representing 12 bogs harvested over three seasons and stored at four temperatures $\left(0,3,5\right.$, and $\left.7^{\circ} \mathrm{C}\right)$ in three levels of humidity. Note the y axis scale represents the angular transformation.

and fruit water potential may influence the development of decay (Cook and Papendick, 1978). The unique complex of fungal pathogens that is responsible for cranberry fruit decay may respond differently to storage $\mathrm{RH}$ than the more common pathogens found in other fruits and vegetables. Understanding and physiological breakdown remained unchanged or increased and there was no increase in physiological breakdown associated with chilling temperatures contrary to previous reports (Anderson et al., 1963; Hruschka, 1970; Levine et al., 1941; Wright et al., 1937). When fruit were held for an additional week at $20{ }^{\circ} \mathrm{C}$, greater amounts of decay and physiological breakdown were observed in fruit previously held at lower temperatures, i.e., 0 and $3{ }^{\circ} \mathrm{C}$. It has been reported that $\mathrm{CI}$ may not be expressed until after fruit is warmed (Morris, 1982). However, when the cumulative effects of both cold storage and the additional $7 \mathrm{~d}$ at $20{ }^{\circ} \mathrm{C}$ were plotted for total marketable fruit (Fig. 4A), total decay (Fig. 4B), and total physiological breakdown (Fig. 4C), very little effect of temperature was observed (Fig. 4). It appears that cooler storage temperatures prolonged the storage life of fruit that are more susceptible to decay or physiological breakdown, but when these fruit were warmed to $20{ }^{\circ} \mathrm{C}$, they rapidly deteriorated. The fact that the total quantity of fruit developing physiological breakdown or decay was not enhanced by prior storage at $0{ }^{\circ} \mathrm{C}$ indicates that no CI was induced.

Unlike many fruits and vegetables, cranberry fruit do not respond strongly to changes in storage temperature between 0 and $10^{\circ} \mathrm{C}$. In this study, there was little significant difference among marketable fruit stored at temperatures ranging from 0 to $7{ }^{\circ} \mathrm{C}$ over 6 months. Similarly, Levine et al. (1941) found rates of spoilage differed by only $0.5 \%$ to $4 \%$ when 'Early Black' and 'Howes' fruit were stored at temperatures ranging from 1.7 to 7.2 ${ }^{\circ} \mathrm{C}$ for 1.5 to 4 months. Most other fruits and vegetables respond more dramatically to storage temperature (Paull, 1999). For example, blueberries stored for 4 weeks at $4.4{ }^{\circ} \mathrm{C}$ had $67 \%$ more unmarketable fruit than those stored at $0{ }^{\circ} \mathrm{C}$ (Hruschka and Kushman, 1963).

The classification of cranberries as chilling-sensitive originates back to several studies, the first being that of Wright et al. (1937) in which large amounts of "sterile breakdown" (physiological breakdown) occurred when 'Early Black' and 'Howes' fruit were held at $-1.1{ }^{\circ} \mathrm{C}$ and to a lesser extent $0{ }^{\circ} \mathrm{C}$. Because the freezing point of cranberries ranges from -1.4 to $-0.9{ }^{\circ} \mathrm{C}$ (Whiteman, 1957), the physiological breakdown that occurred at $-1.1{ }^{\circ} \mathrm{C}$ was most likely freezing and not CI. The cause of physiological breakdown that occurred at $0{ }^{\circ} \mathrm{C}$ is less clear. These fruit may also have experienced freezing if temperature fluctuations in the refrigeration system occurred. Wright et al. (1937) describe the breakdown that occurred at -1.1 and $0{ }^{\circ} \mathrm{C}$ to have a "taste and appearance not unlike those of frozen berries." The next coldest temperature tested was $2.2{ }^{\circ} \mathrm{C}$ at which the fewest unmarketable cranberries were found. Levine et al. (1941) also reported low temperature breakdown when 'Early Black' and 'Howes' fruit were stored at $-1.1{ }^{\circ} \mathrm{C}$ and concluded that the best storage temperature was $1.7{ }^{\circ} \mathrm{C}$, although rates of spoilage did not differ greatly when fruit 


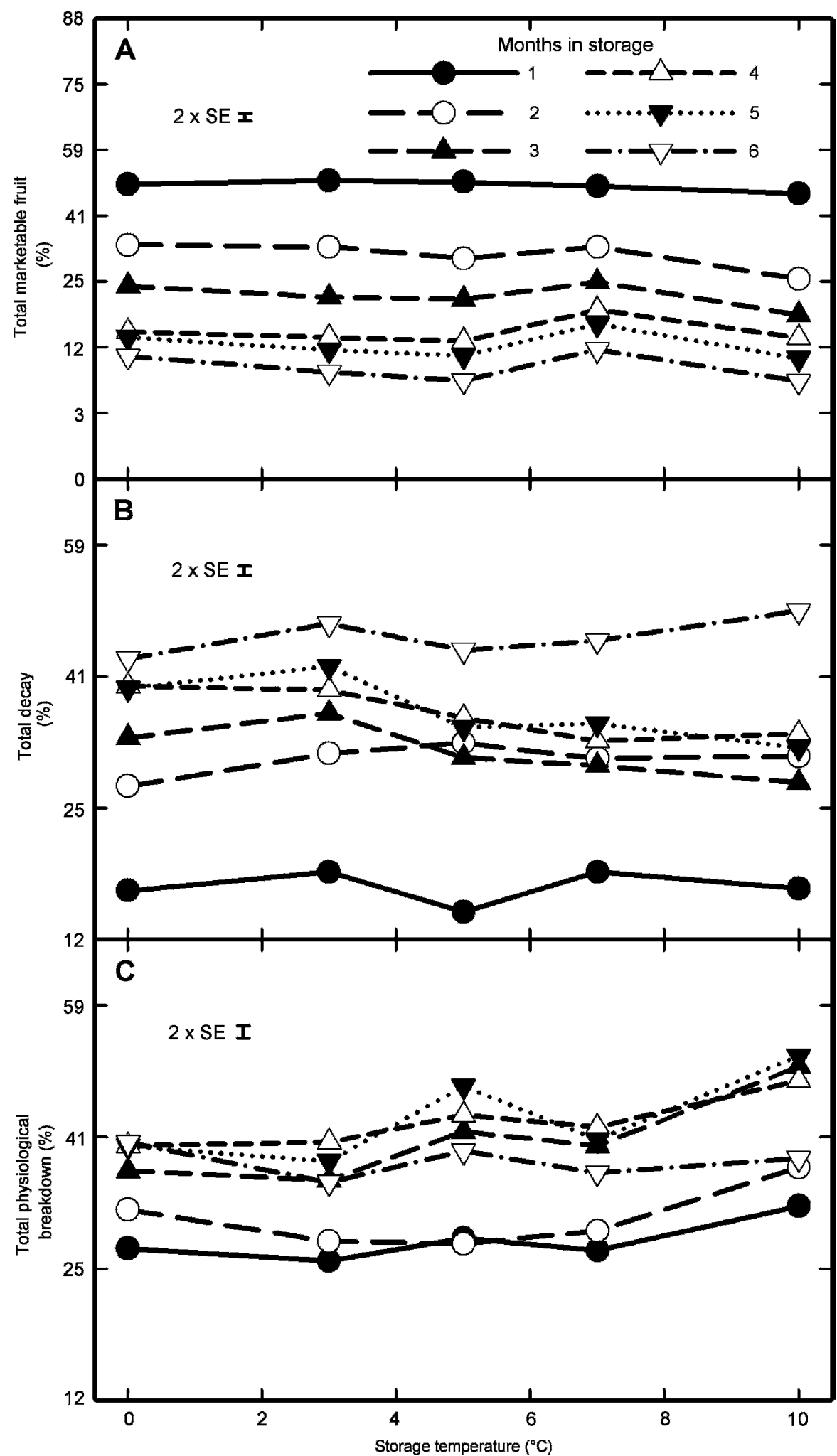

Fig. 4. The effects of storage temperature on the marketability (A), decay (B), and physiological breakdown $(\mathbf{C})$ of cranberry fruit after storage of 1 to 6 months plus an additional $7 \mathrm{~d}$ at $20^{\circ} \mathrm{C}$. Points are means of fruit from 12 bogs harvested over three seasons and stored in three levels of humidity. Note the y axis scale represents the angular transformation.

were stored at temperatures ranging from 1.7 to $7.2{ }^{\circ} \mathrm{C}$ after 7 to 18 weeks of storage. Temperatures between -1.1 and $1.7^{\circ} \mathrm{C}$ were not tested. Anderson et al. (1963) reported little difference in the spoilage of 'Howes' cranberries stored at 0 or $3.3^{\circ} \mathrm{C}$ in storage trials conducted during the 1959 season, but the next season, decay and breakdown was less in fruit stored at 3.3 than $0{ }^{\circ} \mathrm{C}$, which suggested CI. In addition to these observations, Hruschka (1970) provided the strongest evidence for chilling sensitivity of cranberry fruit. He reported an increase in physiological breakdown of 'Early Black' cranberries stored at $0.6{ }^{\circ} \mathrm{C}$ after 12 to 20 weeks compared with fruit stored at $3.3{ }^{\circ} \mathrm{C}$ after an additional week at $21.1^{\circ} \mathrm{C}$. Weekly warming of fruit to $21.1^{\circ} \mathrm{C}$ eliminated this increase in physiological breakdown in fruit stored at $0.6{ }^{\circ} \mathrm{C}$. In storage studies I conducted with 'Stevens', warming fruit stored at 0 or $3{ }^{\circ} \mathrm{C}$ every 2 or 4 weeks for $1 \mathrm{~d}$ reduced both decay and physiological breakdown. These reductions were most apparent after 4 or more months of storage after the additional 1 week at $20^{\circ} \mathrm{C}$ (unpublished data).

The apparent chilling sensitivity of cranberries in these past studies could be a response to $\mathrm{RH}$ rather than temperature. With the exception of the study by Wright et al. (1937), RH was not controlled in these studies. Under most storage conditions where $\mathrm{RH}$ is not actively controlled, the VPD would most likely be lowest at the lowest storage temperature and increase as storage temperature increased. As a result, greater rates of physiological breakdown or decay that were attributed to CI could have been a response to high RH (low VPD).

Cultivar differences also could be responsible for the differences in apparent CI. Wang and Stretch (2001) compared the effects of storage temperatures ranging from 0 to $20^{\circ} \mathrm{C}$ on the antioxidant capacity of 10 cranberry cultivars. Although decay and physiological breakdown of the fruit were not reported, some of the cultivars exhibited symptoms of CI after 3 months of storage at $0{ }^{\circ} \mathrm{C}$ (Wang, pers. comm.).

The wide variation in recommended storage temperatures of fresh cranberries appears to be the result of the lack of response of fresh cranberries to storage temperatures ranging from 0 to $7^{\circ} \mathrm{C}$ and the unexpected effects of $\mathrm{RH}$ on decay and physiological breakdown An increased understanding of the effects of humidity, VPD, and weight loss on fruit physiology and fruit-pathogen interactions would lead to improved methods for the storage of fresh cranberries. In addition, the chilling response of cranberry fruit of various cultivars should be reassessed under controlled humidity conditions.

\section{Literature Cited}

Anderson, R.E., R.E. Hardenburg, and H.C Vaught. 1963. Controlled-atmosphere storage studies with cranberries. Proc. Amer. Soc. Hort. Sci. 83:416-422.

Boone, D.M. 1995a. Blotch rot, p. 32. In: Caruso, F.L. and D.C. Ramsdell (eds.). Compendium of blueberry and cranberry diseases. APS Press, St. Paul, MN.

Boone, D.M. 1995b. Yellow rot, p. 42. In: Caruso, F.L. and D.C. Ramsdell (eds.). Compendium of blueberry and cranberry diseases. APS Press, St. Paul, MN.

Bristow, P.R. and K.D. Patten. 1995. Physiological (sterile) breakdown, p. 68-69. In: Caruso, F.L. and D.C. Ramsdell (eds.). Compendium of blueberry and cranberry diseases. APS Press, St. Paul, MN.

Carris, L.M. 1995. Black rot, p. 31-32. In: Caruso, F.L. and D.C. Ramsdell (eds.). Compendium of 
blueberry and cranberry diseases. APS Press, St. Paul, MN.

Caruso, F.L. 1995. Botryosphaeria fruit rot and berry speckle, p. 32-33. In: Caruso, F.L. and D.C. Ramsdell (eds.). Compendium of blueberry and cranberry diseases. APS Press, St. Paul, MN.

Caruso, F.L. and D.C. Ramsdell. 1995. Compendium of blueberry and cranberry diseases. APS Press, St. Paul, MN.

Ceponis, M.J. and A.W. Stretch. 1983. Berry color, water-immersion time, rot, and physiological breakdown of cold-stored cranberry fruits. HortScience 18:484-485.

Cook, R.J. and R.I. Papendick. 1978. Role of water potential in microbial growth and development of plant disease, with special reference to postharvest pathology. HortScience 13:559564.

Doughty, C.C., M.E. Patterson, and A.Y. Shawa. 1968. Storage longevity of the 'McFarlin' cranberry as influenced by certain growth retardants and stage of maturity. Proc. Amer. Soc. Hort. Sci. 91:192-204.

Forney, C.F. 2003. Postharvest handling and storage of fresh cranberries. HortTechnology 13: 267-272.

Grierson, W. and W.F. Wardowski. 1978. Relative humidity effects on the postharvest life of fruits and vegetables. HortScience 13:570 574.

Hardenburg, R.E., A.E. Watada, and C.Y. Wang. 1986. The commercial storage of fruits, vegetables, and florist and nursery stocks. U.S. Dept. of Agr., Agr. Handbook No. 66.

Hruschka, H.W. 1970. Physiological breakdown in cranberries-Inhibition by intermittent warming during cold storage. Plant Dis. Rep. 54:219-222.

Hruschka, H.W. and L.J. Kushman. 1963. Storage and shelf life of packaged blueberries. USDA Agr. Mktg. Res. Rpt. 612.

Kader, A.A. 1997. A summary of CA requirements and recommendations for fruits other than apples and pears. Proc. 7th Intl. Contr. Atmos. Conf., Davis, CA. 3:1-34.
Kasmire, R.F. and J.F. Thompson. 1992. Selecting a cooling method, p. 63-68. In Kader, A.A. (ed.). Postharvest Technology of Horticultural Crops. Univ. of Calif. Div. Agr. and Natural Res. Publ. 3311.

Levine, A.S., C.R. Fellers, and C.I. Gunness. 1941. Carbon dioxide-oxygen and storage relationships in cranberries. Proc. Amer. Soc. Hort. Sci. 38:239-242.

Levitt, J. 1986. Recovery of turgor by wilted, excised cabbage leaves in the absence of water uptake. Plant Physiol. 82:147-153.

Lidster, P.D. 1990. Storage humidity influences fruit quality and permeability to ethane in 'McIntosh' apples stored in diverse controlled atmospheres. J. Amer. Soc. Hort. Sci. 115:94-96.

Lidster, P.D., P.D. Hildebrand, L.S. Bérard, and S.W. Porritt. 1988. Commercial storage of fruits and vegetables. Publ. 1532/E. Agriculture and Agri-Food Canada, Ottawa, Ontario, Canada.

Morris, L.L. 1982. Chilling injury of horticultural crops: An overview. HortScience 17:161-162.

Norton, J.S. 1982. Bulk storage of cranberries, p. 117-133. In: Modern cranberry cultivation. Cooperative Extension Service, Univ. Mass. Amherst.

O'Brien, F.E.M. 1948. The control of humidity by saturated salt solutions. J. Sci. Instrum. 25:7376.

Oudemans, P.V., F.L. Caruso, and A.W. Stretch. 1998. Cranberry fruit rot in the Northeast: A complex disease. Plant Dis. 82:1176-1184.

Patterson, B.D., and M.S. Reid. 1990. Genetic and environmental influences on the expression of chilling injury, p. 87-112. In: Wang, C.Y. (ed.). Chilling injury of horticultural crops. CRC Press, Boca Raton, FL.

Patterson, M.E., C.C. Doughty, S.O. Graham, and B. Allan. 1967. Effect of bruising on postharvest softening, color changes and detection of polygalacturonase enzyme in cranberries. Proc. Amer. Soc. Hort. Sci. 90:498-505.

Paull, R.E. 1999. Effects of temperature and relative humidity on fresh commodity quality. Postharvest Biol. Technol. 15:263-277.
Payne, R.W. (ed.). 2003. The Guide to GenStat ${ }^{\circledR}$. Release 7.1. VSN International, Oxford, UK.

Pepin, H.S. and D.M. Boone. 1995. End rot, p. 36 37. In: Caruso, F.L. and D.C. Ramsdell (eds.) Compendium of blueberry and cranberry diseases. APS Press, St. Paul, MN.

Polderdijk, J.J., H.A.M. Boerrigter, E.C. Wilkinson, J.G. Meijer, and M.F.M. Janssens. 1993. The effects of controlled atmosphere storage at varying levels of relative humidity on weight loss, softening and decay of red bell peppers. Scientia Hort. 55:315-321.

Pomper, K.W. and P.J. Breen. 1997. Expansion and osmotic adjustment of strawberry fruit during water stress. J. Amer. Soc. Hort. Sci. 122:183189.

Prange, R.K. 2004. Cranberry. In: Gross, K. (ed.). The commercial storage of fruits, vegetables, and florist and nursery stocks. U.S. Dept. of Agr., Agr. Handbook No. 66. 5 Oct. 2006. $<$ http://usna.usda.gov/hb66/056cranberry.pdf $>$.

Spayd, S.E., J.R. Morris, W.E. Ballinger, and D.G. Himelrick. 1990. Maturity standards, harvesting, postharvest handling, and storage, p. 504 531. In: Galleta, G.J. and D.G. Himelrick (eds.). Small fruit crop management. Prentice Hall, Upper Saddle River, NJ.

Stark, R., F.R. Forsyth, C.L. Lockhart, and I.V. Hall. 1974. Processing quality of cranberries after extended storage in $\mathrm{N}_{2}$ atmosphere with low and high relative humidities. Can. Inst. Food Sci. Technol. J. 7:9-10.

van den Berg, L. and C.P. Lentz. 1978. High humidity storage of vegetables and fruits. HortScience 13:565-569.

Wang, S.Y. and A.W. Stretch. 2001. Antioxidant capacity in cranberry is influenced by cultivar and storage temperature. J. Agr. Food Chem. 49:969-974.

Whiteman, T.M. 1957. Freezing points of fruits, vegetables and florist stocks. USDA Market Res Rpt No. 196.

Wright, R.C., J.B. Demaree, and M.S. Wilcox. 1937. Some effects of different storage temperatures on the keeping of cranberries. Proc. Amer. Soc. Hort. Sci. 34:397-401. 